DOI 10.14746/ssp.2021.4.7

\title{
Krzysztof Fedorowicz
}

Uniwersytet im. Adama Mickiewicza w Poznaniu

ORCID ID: 0000-0001-7043-1955

\section{Białoruś wobec pandemii COVID-19. Praktyka i realia}

\begin{abstract}
Streszczenie: Celem artykułu jest przedstawione podejścia władz Republiki Białoruś wobec pandemii COVID-19. Główna hipoteza badawcza przyjęta przez autora głosi, iż Białoruś od początku pandemii zdecydowała się na świadome ignorowanie pojawiającego się zagrożenia epidemiologicznego, przyjmując strategię uspokajania społeczeństwa i bagatelizowania globalnego niebezpieczeństwa. Na podstawie analizy danych dowiedziono, iż większość Białorusinów podczas pandemii COVID-19 całkowicie utraciło zaufanie do państwa i jego organów, które ich zdaniem okazały się niezdolne do podjęcia ochrony swoich obywateli przed negatywnymi skutkami (zdrowotnymi, ekonomicznymi) pandemii.
\end{abstract}

Słowa kluczowe: COVID-19, pandemia, Białoruś, protesty, zdrowie

Niespodziewany wybuch światowej pandemii COVID-19 doprowa1 dził do globalnej dyskusji na temat właściwej strategii państw wobec nowego zagrożenia. Państwa członkowskie Unii Europejskiej wspólnie dyskutowały o tym, jak radzić sobie ze społeczno-gospodarczymi oraz zdrowotnymi konsekwencjami sytuacji. W pierwszych miesiącach pandemii dominowała tendencja zapobiegania i przeciwdziałania.

Szereg państw podejmowało radykalne działania, zmierzające do zahamowania pandemii. Zamykano szkoły, uniwersytety, wprowadzano nakaz pracy zdalnej, ograniczano funkcjonowanie gospodarki poprzez zamknięcie np. restauracji, hoteli i całej branży rozrywkowej. Wobec dalszego pogłębiania się pandemii wprowadzano bardzo surowe ograniczenia, takie jak godzina policyjna, zakaz wyjazdu z kraju czy całkowity lockdown. Mimo powszechnego charakteru tego typu działań w większości państw dotkniętych koronawirusem, w samej Europie i w bezpośrednim sąsiedztwie Polski dwa kraje zdecydowanie wyróżniały się pod tym względem, gdyż praktycznie nie podjęły żadnych działań profilaktycznych. Takie podejście stało się wręcz znakiem firmowym Szwecji oraz Republiki Białoruś. 
Głównym celem artykułu jest przedstawione specyficznego podejścia władz Republiki Białoruś wobec pandemii COVID-19. Główna hipoteza badawcza przyjęta przez autora głosi, iż Białoruś od początku pandemii zdecydowała się na świadome ignorowanie pojawiającego się zagrożenia epidemiologicznego, przyjmując na poziomie oficjalnym strategię uspokajania społeczeństwa i bagatelizowania globalnego niebezpieczeństwa.

W początkowej fazie rozwoju pandemii Białoruś była jedynym poza Szwecją państwem w Europie, które nie wprowadziło kompleksowych ograniczeń dla obywateli i nie wstrzymało funkcjonowania placówek edukacyjnych, uczelni wyższych czy urzędów. Nie zamknięto również granic, mimo podjęcia takich działań przez wszystkie sąsiednie kraje (także Rosję). Jedynie wprowadzono kwarantannę dla osób powracających z zagranicy. Władze zasadniczo koncentrowały się na hospitalizacji zakażonych oraz kwarantannie osób, które miały z nimi kontakt, a także przybyłych z zagranicy.

Z pewnymi niewielkimi ograniczeniami funkcjonują sklepy, punkty usługowe, restauracje, lokale rozrywkowe, kina i teatry. Odbywa się również część imprez masowych, w tym mecze piłki nożnej (liga) i hokeja z osobistym udziałem prezydenta. Białoruska liga piłkarska była jedną w Europie (Bińczyk, 2020) i jedną z nielicznych na świecie, która nie została przerwana z powodu pandemii (poza Białorusią rozgrywek nie przerwała jedynie Nikaragua i Tadżykistan). Materiał o tamtejszej lidze zrobiła nawet amerykańska stacja ESPN (całodobowy kanał sportowy), nazywając ligę białoruską „Ostatnimi rozgrywkami na świecie” (Petrosyan, 2020). Popularność ligi była ogromna, a prawa do transmisji rozgrywek wykupiło osiem telewizji na świecie, w tym potężny rosyjski kanał sportowy Match TV.

Białoruski przywódca Aleksander Łukaszenka od samego początku pandemii wprawdzie nie negował jej istnienia, jednak wielokrotnie publicznie bagatelizował problem, oceniając działania innych państw jako nadmierne, przesadzone i zgubne dla gospodarki (Лукашенко, 2020). Białoruski prezydent w swoich wypowiedziach często określał atmosferę wokół pandemii mianem ,psychozy” i sztucznie kreowanej paniki (Самая страшная, 2020), zalecając obywatelom spokój, wizyty w saunie, pracę fizyczną i umiarkowane dawki alkoholu, co w jego mniemaniu ma chronić przed zakażeniem (Лукашенко оценил, 2020).

Aleksander Łukaszenka powtarzał natomiast konsekwentnie, że Białoruś wybrała właściwy model i że obostrzenia nie są potrzebne, a zgony są wynikiem chorób współistniejących, a nie koronawirusa. Kwaran- 
tanna zatem i inne środki zapobiegawcze zostaną wprowadzone, „kiedy będzie potrzeba". Publicznie nawet krytykował sojuszniczą Rosję, która wbrew zobowiązaniom zawartym w ramach Państwa Związkowego nie konsultując swoich działań z Mińskiem, zamknęła w 2020 roku granicę z Białorusią, tym samym utrudniając współpracę obu państw (Kłysiński, Żochowski, 2020, s. 2). Pojawiły się też publiczne komentarze dotyczące radykalnego ograniczenia skali i zasięgu jednych z największych w Polsce ćwiczeń wojskowych Defender-Europe 20 z udziałem wojsk Sojuszu Północnoatlantyckiego, przeprowadzonych w kwietniu 2020 roku.

Białoruskie władze otwarcie mówiły, iż NATO padło na kolana przed wirusem COVID-19. Ich zdaniem zapowiadane największe od 25 lat ćwiczenia wojskowe NATO zostały zakłócone. Dowodzili, że założonych celów nie udało się osiągnąć, a zdolność USA do szybkiego przemieszczania się i rozmieszczania sił zbrojnych w Europie w celu wspierania innych państw NATO i reagowania na sytuacje kryzysowe została zakwestionowana (Fedorowicz, 2020).

Jednocześnie prezydent Białorusi pozytywnie oceniał stan białoruskiej służby zdrowia, podkreślając przy tym znaczenie utrzymania starych i dobrych w jego opinii radzieckich standardów przygotowania kadr (w tym wirusologów) oraz organizacji opieki zdrowotnej. Symbolicznym potwierdzeniem konsekwencji władz w utrzymaniu polityki ograniczonego zwalczania COVID-19 była kontynuacja przygotowań do uroczystych obchodów 75. rocznicy zwycięstwa w II wojnie światowej, które odbyły się 9 maja 2020 roku w Mińsku mimo negatywnych rekomendacji Światowej Organizacji Zdrowia, petycji obywateli i apeli ekspertów (Bieliaszyn, 2020: 34).

W miarę pojawiania się kolejnych zachorowań wiosną 2020 roku rekomendowano i zalecano jednak zachowanie środków ostrożności, ograniczenie kontaktów i w miarę możliwości nieopuszczanie domów przez osoby starsze, nieodwiedzanie świątyń (Методические рекомендации, 2020). W kwietniu 2020 roku przedłużono do trzech tygodni szkolne ferie. 8 kwietnia 2020 roku wprowadzono też pewne ograniczenia, choć mające raczej charakter zaleceń (np. by odległość między stolikami w restauracjach wynosiła co najmniej 1,5 m). Mimo tego prezydent Łukaszenka konsekwentnie lekceważył płynące z wielu stron (Światowa Organizacja Zdrowia) apele o podjęcie działań profilaktycznych. Pytany przez dziennikarzy o możliwość wprowadzenia kwarantanny (np. na wzór Polski) mówił: „możemy wprowadzić kwarantannę, ale co będziemy jeść?” (Лукашенко о борьбе, 2020). Taka retoryka (i brak konkretnych działań) 
utrzymywała się praktycznie aż do wyborów prezydenckich w sierpniu 2020 roku, po których kwestia pandemii zeszła na Białorusi, w obliczu bieżących wydarzeń, na dalszy plan.

Nerwowe wypowiedzi Łukaszenki, który pandemię nazywa „paniką i psychozą", to efekt presji wynikającej ze świadomości, że wprowadzenie ograniczeń w już chwiejącej się białoruskiej gospodarce doprowadzi do jej upadku (Влияние, 2020). A w konsekwencji do upadku samego prezydenta. Dlatego przyjęta przez władze Białorusi polityka ostentacyjnego pomniejszania skali zagrożenia epidemią, mimo trudnej sytuacji we wszystkich państwach sąsiedzkich, była działaniem wizerunkowym mającym pokazać sprawność i siłę państwa. Ponadto Aleksander Łukaszenka obawiał się, że wprowadzenie poważnych ograniczeń pogłębi notowaną już od stycznia 2020 roku recesję w białoruskiej gospodarce (Olchowski, 2021, s. 23-26).

Białoruski przywódca nie negując występowania epidemii koronawirusa starannie bagatelizuje skalę tego problemu i próbuje rozgrywać sytuację epidemiologiczną dla własnych celów politycznych. Z jednej strony, umacnia swój wizerunek silnego przywódcy zarządzającego stabilnym, bezpiecznym i dobrze zorganizowanym państwem. Z drugiej strony, instrumentalnie wykorzystuje kryzys na arenie międzynarodowej, potępiając Rosję za brak koordynacji i konstruktywnego podejścia do współpracy z Mińskiem, usiłując jednocześnie wykorzystać pojawiające się w związku z pandemią nowe instrumenty międzynarodowej pomocy finansowej, takie jak np. linia kredytowa Międzynarodowego Funduszu Walutowego.

Jednak taka strategia szybko doprowadziła do niekontrolowanego i szybkiego wzrostu zachorowań, co przełożyło się na wzrost niezadowolenia obywateli rozczarowanych zaniechaniami władz. Zdaniem wielu analityków, specyficzna polityka władz białoruskich wobec pandemii COVID-19 stała się jedną z kilku głównych przyczyn wybuchu społecznego niezadowolenia po sfałszowanych wyborach prezydenckich latem 2020 roku.

Fatalny i archaiczny styl komunikacji władzy ze społeczeństwem pokazał słabość białoruskich władz. Udzielane przez prezydenta rady, by chodzić do bani, pić wódkę, pracować w polu i grać w hokeja, nie tylko ośmieszały państwo, ale sprawiały, że obywatele utracili zaufanie do instytucji państwa. Białorusini przestali wierzyć władzom, a poziom frustracji społeczeństwa widoczny był $\mathrm{w}$ mediach społecznościowych - w obliczu alarmujących wieści o braku wyposażenia w szpitalach lu- 
dzie organizowali np. zbiórki pieniędzy na zakup najpotrzebniejszych rzeczy (maseczki, kombinezony). Coraz więcej osób zostawało w domach, a wychodząc, zakładało maski. Wiele firm (np. restauracje) zostało po pewnym czasie zamkniętych ( $\mathrm{z}$ inicjatywy właścicieli a nie nakazów państwowych), co przełożyło się na dodatkowe pogarszanie się sytuacji ekonomicznej.

Pandemia ukazała ewidentną słabość białoruskich władz i ich słabnącą legitymizację. Bezczynność i bezradność władz wpłynęła na ich wizerunek w społeczeństwie, które stało się coraz bardziej rozczarowane. Ucierpiał też wizerunek samego Łukaszenki, który nie zostanie raczej zapamiętany jako silny przywódca, prowadzący naród w trudnym okresie, ale jako przywódca wygłaszający absurdalne tyrady o tym, że nie widzi żadnych wirusów w powietrzu, oraz oskarżający zmarłych, że sami byli sobie winni, ponieważ byli np. zbyt otyli.

Zachowanie Aleksandra Łukaszenki dowodzi jedynie tego, co było zresztą widoczne na długo przed pojawieniem się koronawirusa, że utraty władzy boi się bardziej niż czegokolwiek innego. A dla osobistych ambicji jest w stanie poświęcić życie i zdrowie obywateli swojego kraju (Olchowski, 2020). Nie jest zatem zaskoczeniem, że w obawie przed utratą władzy Łukaszenka oparł się na resortach siłowych i dyktatorskich metodach - pandemia była zaś impulsem, który uruchomił całą sekwencję wydarzeń generujących na Białorusi sytuację rewolucyjną.

Prezydent i białoruskie Ministerstwo Zdrowia w swoich komunikatach zapewniali o dobrym przygotowaniu do walki z pandemią. Jednak na niezależnych portalach internetowych oraz $\mathrm{w}$ sieciach społecznościowych pojawiało się coraz więcej informacji pokazujących sytuację znacznie bardziej dramatyczną od tej prezentowanej oficjalnie (COVID-19 в Беларуси, 2021). Organizacje pozarządowe informowały jednak o przeciążonej służbie zdrowia i braku wyposażenia medycznego oraz środków ochrony. Prowadziło to do wzrostu niezadowolenia kolejnych grup społecznych i manifestowania braku zaufania do oficjalnych źródeł informacji o rozprzestrzenianiu się COVID-19 na Białorusi. W rezultacie w przestrzeni medialnej funkcjonowały dwa zupełnie odrębne, często wykluczające się przekazy na ten temat (Mojeiko, 2020).

Postawa Łukaszenki wpłynęła na sposób działania resortów odpowiedzialnych za bezpieczeństwo. 21 marca 2020 r. za priorytetowe zadanie do realizacji przez KGB prezydent uznał przeciwdziałanie rozpowszechnianiu informacji o skali rozwoju pandemii. Podobny mechanizm tuszowania rzeczywistej sytuacji epidemiologicznej został 
wprowadzony w siłach zbrojnych, gdzie nawet w obliczu pandemii nie przerwano ćwiczeń jednostek wojskowych odbywających się w ramach ogłoszonego przez prezydenta sprawdzianu gotowości bojowej i mobilizacyjnej.

Władze reagowały również na przejawy zaniepokojenia społecznego. Wszyscy białoruscy lekarze zostali zmuszani do podpisania pisemnego zobowiązania o zachowaniu tajemnicy służbowej pod groźbą odpowiedzialności karnej. W ten sposób władze chcą się zabezpieczyć przed przenikaniem do mediów prawdziwych informacji o liczbie i stanie zdrowia chorych, a także o kondycji służby zdrowia. Dynamicznie rośnie jednak liczba chorych z diagnozą zapalenia płuc, którego objawy są zbliżone do objawów COVID-19. W związku z tym zachodzi podejrzenie, że lekarze są zmuszani do niezgodnego z prawdą klasyfikowania części chorych, tak aby ukryć prawdziwą skalę zachorowań.

W 2020 r. podczas wiosennej fali pandemii liczba chorych zwiększała się szybko; każdego dnia stwierdzano zakażenie u ok. 800 osób (w Polsce było to wówczas ok. 300-400 przypadków, na Ukrainie ok. 500). Pod koniec kwietnia 2020 roku na Białorusi było ok. 11 tys. zarażonych, 75 osób zmarło. W połowie września 2020 roku ogólna liczba zarażonych wynosiła ok. 75 tys. osób, a w połowie grudnia 2020 nieco ponad 160 tys. - przy czym z tej liczby ok. 1300 osób zmarło, 140 tys. wyzdrowiało - dziennie przybywało natomiast 2 tys. nowych przypadków (Коронавирус, 2021).

Mimo bierności władz, które nie podjęły istotnych działań w walce z pandemią, i mimo trwających od lata 2020 wielotysięcznych manifestacji wydaje się jednak, że Białoruś ucierpiała mniej niż państwa sąsiednie - w przeliczeniu na milion mieszkańców zmarło ok. 130 osób, podczas gdy na Ukrainie ok. 360, ponad 300 w Rosji i ponad 600 w Polsce (wg oficjalnych białoruskich danych, kwestionowanych przez wiele międzynarodowych organizacji). Warto podkreślić, że popularna w początkowym okresie pandemii teza, jakoby państwa autorytarne lepiej sobie radziły z pandemią koronawirusa, nie znalazła uzasadnienia - czego przykładem jest również Rosja.

W lipcu 2021 roku na Białorusi chorowało ok. 1,2 tys. osób, a około 423 tys. osób przeszło już zakażenie koronawirusem. Liczba ofiar śmiertelnych to ok. 3,3 tys. osób (w ciągu doby jest to średnio 10 przypadków). Przeprowadzono około 7 mln testów (przy ogólnej populacji kraju liczącej 9,35 mln osób) (Актуальная информация, 2021). Z kolei według stanu z 8 grudnia 2021 roku na Białorusi chorowało ok. 1,7 tys. osób, a około 657 tys. osób przeszło już zakażenie koronawirusem. Liczba ofiar 
śmiertelnych to ok. 5,2 tys. osób (w ciągu doby jest to średnio 15-17 przypadków). Przeprowadzono około 10,5 mln testów (przy ogólnej populacji kraju liczącej 9,35 mln osób) (Статистика распространения, 2021).

29 grudnia 2020 r. na Białorusi rozpoczęła się pierwsza faza masowych szczepień przeciwko COVID-19. Władze zdecydowały się na masowe szczepienia wyprodukowanym przez Rosję preparatem Sputnik V. Białoruś jako pierwsze państwo poza Rosją zarejestrowała tę szczepionkę. Importowana jest też chińska CoronaVac i prowadzone są rozmowy z Indiami. Pod koniec marca 2021 r. firma Biełmedpreparaty rozpoczęła licencyjną produkcję szczepionek Sputnik - część z nich ma być kierowana na eksport. Szczepienia objęły w pierwszej kolejności osoby z grup ryzyka (za takie uznano pracowników socjalnych i służby zdrowia oraz nauczycieli), np. w obwodzie brzeskim szczepienia rozpoczęto już w styczniu 2020 roku. Jako następni szczepieni mają być pracownicy handlu, gastronomii i służb komunalnych oraz osoby powyżej 60 roku życia. Z kolei w kwietniu 2021 r. rozpoczęły się na szeroką skalę szczepienia populacyjne dla wszystkich chętnych. Szczepienie ma charakter dobrowolny i jest bezpłatne. Sam prezydent zadeklarował, że nie przyjmie szczepionki, gdyż uważa, że przebyta infekcja uodparnia go na kolejne zakażenia.

Zdaniem lekarzy, Białorusini w większości chcą się szczepić. Wstępnie planowano zaszczepienie do czerwca 2021 roku $1 \mathrm{mln}$ osób, a do jesieni ok. $4 \mathrm{mln}$. Jednak do lipca 2021 r. zaszczepiono około 900 tys. osób (najwięcej w Mińsku - ok. 270 tys.), z których 600 tys. otrzymało dwie dawki szczepionki (Князева, 2021). Wg danych z grudnia 2021 roku na Białorusi w pełni zaszczepionych jest tylko $28 \%$ społeczeństwa, czyli około 2,7 mln (Coronavirus, 2021).

Jednak COVID-19 jest instrumentem polityki i propagandy. Ministerstwo Zdrowia podkreśla, że ściśle i efektywnie współpracuje ze służbami rosyjskimi i że po osiągnięciu odpowiedniej liczby zaszczepionych zniesione zostaną ograniczenia w przemieszczaniu się do i z Rosji. Z kolei Aleksander Łukaszenka podpisał dekret nakazujący do 2023 r. opracowanie i wyprodukowanie białoruskiej szczepionki. Jest to - jego zdaniem - „sprawa honoru”.

Z nieoficjalnych danych wiadomo, że wcześniej szczepionkę podano niektórym pracownikom administracji prezydenta. Otrzymała ją m.in. rzeczniczka prasowa Alaksandra Łukaszenki Natalia Ejsmont, co nie uchroniło jej przez zakażeniem koronawirusem (podobnie jak wielu in- 
nych pracowników z najbliższego otoczenia głowy państwa). Również sam prezydent Aleksander Łukaszenka w lipcu 2020 roku zaraził się COVID-19 (Krzysztonek, Wolska, 2020).

Pod koniec września 2020 r. Białoruś wprowadziła ograniczenia dotyczące możliwości wjazdu na swoje terytorium przez przejścia drogowe (nie dotyczyły one obywateli Białorusi i Federacji Rosyjskiej, obcokrajowców ze zgodą na pobyt czasowy lub stały na terytorium Białorusi, kierowców transportu międzynarodowego, członków oficjalnych delegacji itp.). W przypadku większości obcokrajowców wjazd czy tranzyt przez Białoruś możliwe są wyłącznie przez międzynarodowe lotnisko w Mińsku. Konieczne jest posiadania aktualnego, ważnego tylko trzy dni negatywnego wyniku testu PCR na COVID-19. Osoby wjeżdżające na terytorium Białorusi muszą odbyć także 10-dniową kwarantannę (Нормативно-правовые, 2021). Od 21 grudnia 2020 r. władze Białorusi wprowadziły także czasowy zakaz wyjazdu swoich obywateli przez lądowe przejścia graniczne.

Trudno definitywnie stwierdzić, czy podjęte działania miały na celu realne ograniczenie rozprzestrzeniania się wirusa, czy stanowiły jedno z narzędzi izolowania i tłumienia oporu społecznego po sfałszowanych w 2020 r. wyborach prezydenckich. Wyłączenie z ograniczeń Federacji Rosyjskiej i jej obywateli oraz brak działań zmniejszających mobilność ludności wewnątrz państwa uzasadniają tę drugą ewentualność (Szabaciuk, 2021).

Białoruś należy do grona państw, które nie zdecydowały się na wprowadzenie radykalnych ograniczeń w przemieszczaniu się ludności ani nakazu noszenia maseczek ochronnych w miejscach publicznych. Nie zawieszono także pracy placówek oświatowych ani instytucji publicznych. Władze starają się bagatelizować zagrożenie, przez co również ogranicza się koszty walki z pandemią COVID-19. Z punktu widzenia dotychczasowego prezydenta ważniejsze było zachowanie pozorów panowania nad sytuacją, niż troska o dobro obywateli. COVID-19 odegrał na Białorusi ważną rolę polityczną. Wiosną 2020 r. reakcja władz na pandemię pogłębiła niezadowolenie społeczne, co w konsekwencji przyczyniło się do bezprecedensowych protestów Białorusinów. Pandemia służyła też jako pretekst do kontrolowania protestującego społeczeństwa - tak jak w grudniu 2020 r., kiedy zamknięto granice Białorusi, tłumacząc to walką z koronawirusem.

Program masowych szczepień na Białorusi realizowany jest w ścisłej współpracy z Federacją Rosyjską. Białoruś jest pierwszym państwem po 
Rosji, które zdecydowało się na dopuszczenie do obrotu rosyjskiej szczepionki przeciwko COVID-19, mimo iż opinie międzynarodowych ekspertów oraz sam przebieg badań klinicznych na Białorusi budzą poważne wątpliwości co do skuteczności i przede wszystkim bezpieczeństwa stosowania preparatu Sputnik V. Decyzja Białorusi o rozpoczęciu masowych szczepień podyktowana jest także względami politycznymi. Problemy $\mathrm{z}$ rejestracją rosyjskiego preparatu w części państw odbijają się negatywnie na wizerunku Rosji, która do tej pory promowała swoją szczepionkę jako pierwszą zarejestrowaną, skuteczną i w pełni bezpieczną. Białoruski program masowych szczepień dopuszczoną do użytku w ekspresowym tempie szczepionką może przekonać niezdecydowane państwa co do skuteczności preparatu.

Strona białoruska instrumentalnie wykorzystuje pandemię, która służy nie tylko do kontrolowania społeczeństwa, ale też zacieśniania relacji z Rosją oraz jako element propagandy sukcesu. Białoruś produkuje na licencji rosyjską szczepionkę Sputnik V, podkreśla się też współpracę medyczną i humanitarną z Rosją. Szczepienie Białorusinów odbywa się jednak bardzo powoli, a statystyki dotyczące COVID-19 najprawdopodobniej były i są fałszowane (Olchowski, 2021a). Zdaniem niezależnych ekspertów i międzynarodowych organizacji białoruskie władze nie chcą okazywać słabości i celowo zatajają prawdziwe oblicze pandemii. Eksperci nie dowierzają oficjalnym danym epidemicznym publikowanym przez Mińsk. Prawdziwa skala pandemii w Białorusi pozostaje nieznana. Choć naukowcy próbują ją oszacować. Np. wg danych amerykańskiego The Institute for Health Metrics and Evaluation (IHME) od marca 2020 do maja 2021 roku w Białorusi było 472 zgonów na 100 tys. mieszkańców. A według oficjalnych statystyk - 28 zgonów. $\mathrm{Z}$ modelu amerykańskich naukowców wynika, że Białoruś jest jednym z najbardziej dotkniętych pandemią krajów świata - należy do 20 krajów o najwyższych współczynnikach umieralności z powodu COVID-19 (Estimation, 2021).

Podsumowując należy zauważyć, iż polityka białoruskich władz w kwestii pandemii COVID-19 od samego początku charakteryzowała się świadomym ignorowaniem niebezpieczeństwa z przyczyn głównie politycznych i gospodarczych. Preferowano wizerunek kraju niepoddającego się masowej światowej psychozie, dającego sobie radę wg własnych „recept” i specyficznej profilaktyce. Zdrowie i życie obywateli Białorusi okazało się mniej ważne niż wskaźniki gospodarcze, wizerunek przywódcy i konieczność „,wygrania” kolejnych wyborów prezydenckich 
przez Aleksandra Łukaszenkę. Tym samym większość Białorusinów podczas pandemii COVID-19 całkowicie utraciło zaufanie do państwa i jego organów (После пандемии, 2021), które okazały się niezdolne do podjęcia choćby próby ochrony swoich obywateli.

\section{Bibliografia}

Bieliaszyn W. (2020), Parada na Białorusi. Łukaszenka zarazy się nie boi, „Polityka", https://www.polityka.pl/tygodnikpolityka/swiat/1955888,1,parada-nabialorusi-lukaszenka-zarazy-sie-nie-boi.read, 16.07.2021.

Bińczyk J. (2020), Dlaczego na Białorusi gra pitkarska liga? „Bo prawdziwi mężczyźni nie boją się koronawirusa”, „Gazeta Wyborcza”, 5.04.2020.

Coronavirus (COVID-19) Vaccinations, https://ourworldindata.org/covid-vaccinations, 8.12.2021.

Estimation of excess mortality due to COVID-19, http://www.healthdata.org/specialanalysis/estimation-excess-mortality-due-covid-19-and-scalars-reportedcovid-19-deaths, 18.07.2021.

Fedorowicz K. (2020), Białoruś wobec manewrów wojskowych Defender-Europe 20 w Polsce, ,Komentarz Instytutu Europy Środkowej w Lublinie”, nr 165 (68/2020), https://ies.lublin.pl/komentarze/bialorus-wobec-manewrow-wojskowych-defender-europe-20-w-polsce/, 16.07.2021.

Kłysiński K., Żochowski P. (2020), Zaklinanie rzeczywistości: Białoruś w obliczu pandemii COVID-19, „Komentarze OSW. Ośrodek Studiów Wschodnich”, nr 324.

Krzysztoszek A., Wolska A. (2020), Białoruś: Łukaszenka był zakażony koronawirusem, https://www.euractiv.pl/section/polityka-zagraniczna-ue/news/bialorus-lukaszenka-byl-zakazony-koronawirusem/, 16.07.2021.

Mojeiko V. (2020), Coronavirus in Belarus: Controversial Decisions and European Solidarity, Belarusian Institute for Strategic Studies, https://belinstitute.com/ en/article/coronavirus-belarus-controversial-decisions-and-european-solidarity, 15.07.2021.

Olchowski J. (2020), Białoruś wobec COVID-19 - bezradność i bezczynność, „Komentarz Instytutu Europy Środkowej w Lublinie”, nr 180 (83/2020), https:// ies.lublin.pl/komentarze/bialorus-wobec-covid-19-bezradnosc-i-bezczynnose/, 16.07.2021.

Olchowski J. (2021), COVID-19 w państwach Partnerstwa Wschodniego: Biatoruś, w: Partnerstwo Wschodnie $w$ dobie pandemii COVID-19: perspektywa UE i państw partnerskich, red. B. Piskorska, J. Olchowski, Lublin.

Olchowski J. (2021a), ,,Stabilizacja” sytuacji na Białorusi, „Komentarz Instytutu Europy Środkowej w Lublinie", nr 386 (83/2021), https://ies.lublin.pl/komentarze/stabilizacja-sytuacji-na-bialorusi/, 18.07.2021. 
Petrosyan A. (2020), How Belarus is fighting the coronavirus: vodka first, football second, https://www.espn.com/soccer/belarus/story/4078805/how-belarus-isfighting-the-coronavirus-vodka-firstfootball-second, 16.07.2021.

Szabaciuk A. (2021), Razem z ,bratnim narodem”. Szczepienia przeciwko wirusowi SARS-CoV-2 na Białorusi, „Komentarz Instytutu Europy Środkowej w Lublinie", nr 305 (2/2021), https://ies.lublin.pl/komentarze/razem-z-bratnim-narodem-szczepienia-przeciwko-wirusowi-sars-cov-2-na-bialorusi/, 19.07.2021.

Актуальная информация по предупреждению инфекции COVID-19, http:// minzdrav.gov.by/ru/dlya-belorusskikh-grazhdan/COVID-19/, 16.07.2021.

Влияние пандемии соvіd-19 на экономические и соииальные процессы в Беларуси, http://library.fes.de/pdf-files/bueros/ukraine/17386.pdf, 8.12.2021.

Князева Е. (2021), Более 269 тыс. человек привились от COVID-19 в Минске - как идет вакиинация в столице, https:/www.belta.by/comments/view/bolee269-tys-chelovek-privilis-ot-covid-19-v-minske-kak-idet-vaktsinatsija-vstolitse-7840/, 16.07.2021.

Коронавирус в Беларуси: статистика, https://tomin.by/news/belarus/26010koronavirus-v-belarusi, 8.12.2021.

Лукашенко: Белоруссия сохранила экономику, отказавиись от комендантского часа в пандемию, https://tass.ru/ekonomika/12087785, 8.12.2021.

Лукашенко оченил успехи Белоруссии в борьбе с пандемией выме западных, https://lenta.ru/news/2021/10/02/lukasenko_pandemia/, 8.12.2021.

Лукашенко о борьбе с коронавирусом: занимаемся без шума и пыли, https://www. belta.by/president/view/lukashenko-o-borbe-s-koronavirusom-zanimaemsjabez-shuma-i-pyli-384934-2020/, 8.12.2021.

Методические рекомендации по профилактике коронавирусной инфекции (COVID-19), http://minzdrav.gov.by/ru/novoe-na-sayte/metodicheskierekomendatsii-po-profilaktike-covid-19-/, 8.12.2021.

Нормативно-правовые акты, регулирующие правовые отношения граждан Республики Беларусь, иностранньх граждан, лии без гражданства и субъектов хозяйствования всех форм собственности в условиях распространения COVID-19, http://minzdrav.gov.by/ru/dlya-belorusskikh-grazhdan/ COVID-19/faq_covid-19.php\#faq06, 8.12.2021.

После пандемии: солидарность, политика, атомизация, https://belinstitute.com/ be/article/posle-pandemii-solidarnost-politika-atomizaciya, 8.12.2021.

Самая страшная эпидемия - это паника. Лукашенко обсудил с эпидемиологами ситуацию в стране, https://www.belta.by/president/view/lukashenko-sobralsoveschanie-po-epidemiologicheskoj-situatsii-v-belarusi-383883-2020/, 8.12.2021.

COVID-19 в Беларуси: реакиии общества, https://belinstitute.com/be/article/covid19-v-belarusi-reakcii-obschestva, 8.12.2021.

Статистика распространения. Официальные данные Минздрава, https:// stopcovid.belta.by/, 8.12.2021. 


\section{Belarus and the COVID-19 Pandemic. Practice and Reality}

\section{Summary}

The article's aim is to present the approaches of the authorities of the Republic of Belarus toward the COVID-19 pandemic. The main research hypothesis is that Belarus decided to consciously ignore the emerging epidemiological threat from the beginning of the pandemic by adopting a strategy of appeasing the society and downplaying the global danger. Based on the data analysis, it has been proved that most Belarusians during the COVID-19 pandemic completely lost their trust in the state and its authorities, which in their opinion turned out to be unable to protect their citizens against the negative (health, economic) effects of the pandemic.

Key words: COVID-19, pandemic, Belarus, protests, health 